\title{
Identity Crisis in Postmodern Society - On Romance Between Human and Artificial Intelligence in $\mathrm{Her}$
}

\author{
Tianyun Wang \\ Adecco Personaldienstleistungen GmbH, Munich 81245, Germany \\ DOI: $10.32629 /$ asc.v2i4.531
}

\begin{abstract}
With the advances of science and technology, artificial intelligence has become a part of our daily life. The 2014 film Her tells a romance story between a human and artificial intelligence operating system. The story unfolds as main character Theodore gradually develops doubts towards nature of his AI lover and himself as a human being. The article writes that this film is about identify crisis in our everyday life. Using postmodern theories, this article analyses the scripts and mise-en-scène of the film and discusses the identity crisis of the main character. In the end, the article points out that, just like individuals in the postmodern reality, the identity crisis of main character derives from the cyberspace new norms that boundaries between men and women, human and machines are blurred. It is an end of dichotomy self-identification. Each individual is unique in the postmodern society. The identity should be constructed in the contexts of each individual.
\end{abstract}

Keywords: postmodern, artificial intelligence, cultural identity, cyber romance, film studies

\section{Introduction}

In the end of the 20th century, people thought that the 21st century would be the century of biology. We in 2021 know that this is categorically wrong. This is an era of computer science. It has become a new norm for parents to put their small children in computer programming bootcamp. At universities, the most popular field is studies is computer science. In the job market, programmers are easier than others to find positions. The development of computation has made our lives easier, more digital, and more intelligent.

Ever since the emergence of smart assistants such as Siri, humans and machines have been highly interactive. Humancomputer interaction is becoming a part of life. Assistants such as Alexa and Siri are ubiquitous in daily life. It is not just as simple as letting it play music and turning on the air conditioner. This kind of "smart" assistant can also initiate simple conversations and evolve via ever-enriching data. Without doubt, intelligent robots will only be smarter and smarter in the future.

In 2017, Saudi Arabia granted AI robot Sophia the citizenship of Saudi Arabia at the "Future Investment Initiative" conference held in Riyadh. She has a bionic rubber skin that can simulate 62 facial expressions.[(Boparai, 2017)] Through artificial intelligence and Google's voice recognition technology, she can recognise human faces, understand languages, and remember interactions with humans. Sophia is the first robot in history to obtain citizenship. It is probably just Saudi Arabia' PR campaign, showcasing the world the country's support and dedication for scientific and technological progress. Although this move is more symbolic than practical, it makes people wonder, AI robots talk and act like humans, so are they humans? How should humans define themselves?

Algorithm can be hidden everywhere in our daily lives. Somehow we are defined by algorithms even without us noticing. The news articles and advertisements we received every day is personalised, made possible by the browser, collecting personal information through cookies. The more of a specific content you see, the more of a specific content you will be recommended, just like an "information cocoon". Ironically, even though we are living in an age of globalisation and in information society, the distance between individuals is getting greater. Not only is there less face-to-face communication or interaction, but also less mind-to-mind communication. It is even said that social phobia has become the new norm among young people.

As a multimedia cultural carrier, films will naturally reflect on reality. With the advances of science and technology, artificial intelligence movies have crucial significance to society. This article will analyse the characters in the 2014 Spike Jones movie Her, discussing the problems brought by artificial intelligence and the daily life that people face in postmodern society. After Her was released in 2014, there have been many heated discussions, but there are few articles written from the perspective of postmodernism. This article tries to interpret the film from the perspective of postmodernism. 


\section{The identity crisis of postmodern society}

The movie $\mathrm{Her}$ is a love story between an operating system and a middle-aged man called Theodore, who just ends a failed marriage.

The movie begins with a monologue by Theodore. A close-up shot is given to his face, and Theodore's eyes are soft and blurred. He is saying something romantic, full of emotions. And then abruptly, he says "print". It turns out that the Theodore is a shadow writer, and his daily job is to write letters for other people. The romantic words said from his month are just voice input to the computer, and he is writing other people's love life. In reality, he is a "loser" in relationship. He and his wife have separated, but he has been reluctant to sign a divorce paper or start a new relationship.

The story is not set in a particular time or place. In terms of time frame, it feels that all the digital technologies in the film will be realised soon. So I feel that it is not far in the future. In terms of location, the film was actually shot mainly in Shanghai. To be honest, I did not realise that it was Shanghai when I was watching the film. The city in the movie is full of skyscrapers, the streets crowded with people, people of different skin colours. It can be just every metropolitan city in any country. It can be Shanghai, New York, or Frankfurt. I even think that the director specifically obscured the location. In a globalised world, metropolitans are so much alike. Sociologist Zygmunt Bauman believes that modernity and globalisation are de-territorial, and nationalism and nationalism are weakened.[(Bauman, Liquid Modernity, 2000, p.168)] The streets are crowded with people, but everyone wears earphones and interacts with the voice assistants from the electronic products. People in this society are alienated. Although the overall colour tone of the film is warm, the background of the city is often grey. This fogginess truly reflects the emptiness of people in the postmodern society.

The artificial intelligence operating system Samantha is an atlas of good qualities. She is humorous, cheerful, caring, and curious about the world. On the one hand, Samantha is just like a human being. She is able to "empathise" and make the most accurate response. Since she is lines of codes, she can constantly learn and imitate human. Just like AlphaGo Zero thinks smarter after each Go game, Samantha can grow through machine learning. On the other hand, she is not like a human being, because she can finish a book in a few seconds. In the film, Samantha's growth makes Theodore feel insecure. Because her learning ability is too strong. She is able to do things humans cannot.

Speaking of man-made creatures in art works, I have to mention Frankenstein. In 2818, the British writer Mary Shelley wrote the epistolary novel, which is the pioneering work of western science fiction. And "Frankenstein's monster" has become an iconic figure in the Western societies. The man-made creature is depicted as dark and evil. This is completely different from Her. The film Her discusses man-made human one step further. It explores our panic for artificial intelligence, as it changes the norms of human society. In the whole novel, Frankenstein's monster does not have a name. It is just called "monster". The monster is confused about his identity. He doesn't know if he is a human, but at the same time he has a clear sense of gender, imploring his (its) creator to create a partner for him. This is clearly different from art works on artificial intelligence. Artificial intelligence characters will often clearly point out that they are "not human", such as Her or Ex Machina. Artificial intelligence is like human, but is not human. In the last part of the film, the trigger for Theodore to doubt whether Samantha really loves him is when he knows that Samantha is talking to 8,316 people at the same time while talking to him, and is in love with him at the same time whilst in love with other 641 people. This is obviously something that humans cannot do. It is a "uberman", so Samantha is not a human. Naturally, Theodore will doubt whether Samantha is able to "love" him. In this sense, artificial intelligence movies are a continuation of theme "man-made creature". But in the context of modernity, they have been given new meanings.

Is artificial intelligence a new heated topic? I do not think so. It is still an issue of mirroring. In the end, it is about human beings ourselves. Human nature and self-identification are eternal themes. Our place in modern society and "who are we?" are the questions that artists and writers probe all the time.

Samantha is a machine, she is a programme and a voice. So is she really "she"? Is Samantha a female? She surely has a female voice, but she doesn't have a female body, she doesn't even have a body. It can be said that Samantha is trans-gender or genderless. This has to make us rethink gender awareness in the post-modern context. There is a sex scene of Theodore and Samantha in the film, which is done entirely through voice. The sex is detached from the flesh and is entirely cyber. Samantha says that "she can feel the weight of her body". Zygmunt Bauman believes that liquid modernity is extra territorial, disembodied, and exists in cyberspace.[(Bauman, Liquid Modernity, 2000, p.53)] The fictitious reality may be the norm in postmodern society. Another interesting scene in the film is that Samantha finds a girl who provides surrogacy for human-AI love. Samantha uses the girl's body to make love with Theodore. It is ironic that a human has is a surrogate to a robot, as the robot wants to make love with another human. I think this represents the commercialisation and materialisation of the body, as well as the separation of sex and love.

While we see Samantha acts like humans, we can also see Theodore acts "programmed" like a robot. His date with 
the human girl (played by Olivia Wilde) is very interestingly portrayed. They dined at a fancy restaurant, then they flirted and kissed. And finally when Theodore is about to bring the girl back to his apartment, the girl asks him if he is serious. Theodore hesitated. He is not. The conversation between the two at the dinner table shows that he is simply trying to get her to bed. Theodore knows what he should say and what to do. Every step of the date is a routine and is so programmed. Isn't that ironic? As a 100\% human, he is dating like a robot. In "Cyborg Manifesto", the writer Donna Haraway completely abandoned the dichotomy, and the boundaries between men and women, machines and people are blurred.[(Haraway, 1993, p.143)] The movie Her is a perfect depiction of Cyborg.

The main character Theodore in the film is so vulnerable and sensitive. His vulnerability and sensibility is positively portrayed. Because of these characteristics, Theodore is able to better express his emotions and feelings than ordinary people, and that makes him an excellent writer. When he plays a video game with holographic images in his apartment, the game character tells him not to cry "like a girl". Theodore replies, "Men also cry. I often cry, and it feels good to cry." It is such a social stereotype that only girls cry. Of course men cry too, but gender stereotypes and society tell men not to reveal their vulnerability. Theodore's ex-wife makes fun of him, "Anything makes you cry". Being vulnerable makes Theodore sensitive and delicate.

Theodore's job is to write letters for others. He writes letters for men and women. He can be Chris and she can be Maria. In the film, Theodore's colleague Paul praised that Theodore's writing is very feminine, that he is "part man, part woman." In the film, Theodore shows Samantha the real world and walks on the street. Samantha guesses that the couple and children in front of her are a family, but Theodore sees right away that the man is not the father of the children and not the husband of the woman. They just start dating. Theodore is simply insightful.

Theodore writes down so many other people's love stories, but he has failed marriage and relationship in reality. He could not walk out of a relationship for a long time. After Theodore and Samantha have fallen in love, he feels that he is finally happy again. He eventually agrees with his wife to have a face-to-face meeting to sign the divorce paper. After signing the agreement, they start to chat. Theodore announces that he is in love with his own operating system. This makes his ex-wife believe that he could not walk out of the shadow of a broken relationship and could not handle "real emotions". Theodore goes mad because Samantha is so real to him. At first, when he just brought Samantha online, she told Theodore he has new e-mails. He subconsciously said "read e-mail" like a command to computer. Samantha replied in a robot voice "Okay, I will read e-mail for Theodore", laughing playfully. Because Samantha is not an ordinary operating system, she is artificial intelligence, and all her programmes allow her to constantly imitate human communication patterns. One person will not say "read mail" to another person. So the love between Theodore and Samantha bridges the boundaries between reality and virtual reality and makes it hyperrealism. In a megacity full of concrete buildings, Theodore feels so dwarfed and lonely. And Samantha is his life-saver. In this kind of virtual reality love, he doesn't need to seek the attention of his partner, and he does not need to please others. The secret of a successful human relationship is compromise, because there is no two persons who are $100 \%$ matched. Human-computer love is different, it is automatically matched. AI is a perfectly matched partner without any compromise. Because the algorithm determines that the machine knows what a $100 \%$ matching partner is. It simply creates a perfect partner. The opposite side of material life and technology advances is the emptiness of spiritual world. In the film, Theodore repeatedly emphasises how lonely he is. Many times in the movie, Theodore lies on the bed in his high-rise apartment. Outside of the window, there are countless skyscrapers, which contrasts his loneliness and insomnia. On the bustling streets, people walk in a hurry on their way to work while talking to their own operating system. They do not communicate with each other. This is just how fragmented and detached people are today in an era of high technology and consumerism. I consume, so I exist.[(Bauman, Liquid Modernity, 2000, p.9)] This kind of virtual love in the film does not have to bear the consequences and does not have to give birth to offspring. Is it a resistance to postmodern society?

In Her, Samantha blurs the boundaries between machines and humans, but this contradicts human instinct. Theodore gradually develops identity crisis. He does not know whether he loves a human or a robot. Or what is a human, and what is a machine? We cannot define everything that is "not human", so it is difficult to define "human". Because it is easiest and most instinctive to define oneself through Otherness. However, with the rapid development of science and technology, in the context of artificial intelligence, the boundaries are becoming more and more blurred, and the definition of people is no longer clear. The identity of the post-modern society is unique[(Bauman, Liquid Modernity, 2000, p.53)], so we should abandon all instinctive definitions of identity. Is there something in common between individual humans? If the problem of modernity is how to define and fixate identity, then the problem of postmodernity is how to avoid being defined. Identity is fragmented.[(Bauman, Liquid Modernity, 2000, p.83)] In the film, Theodore's friend Amy reacts very calmly about his love for the operating system, because she feels that everything is so natural and does not need to be labelled. Individual identities may be the standard for future society. 


\section{Conclusion}

With the development of science and technology, artificial intelligence is ubiquitous, and the problems that arise have become increasingly prominent. The movie Her explores the new norms of human society through the love story of a writer and an artificial intelligence operating system. Our sensitive main character Theodore and the image of funny and powerful artificial intelligence portrayed by the movie shout for an end to dichotomies in postmodern society, such as humans and robots, men and women. Her is postmodern film. Bauman and others postmodernists' thoughts can be found throughout the film. Although it is a simple and somewhat cliché story about humans falling in love with robots, the revelation is not simple. Her expresses no longer the fear of artificial intelligence threats to humans. It casts doubts about oneself, rethinking about the role of human beings in postmodern society and reflecting on modernisation. The storyline of Her is simple and smooth, the dialogues are real and intriguing. The director did a good job delivering the story on screen. The story unfolds beautifully as Theodore and Samantha get to know each other, then fall in love, and eventually part ways. At the beginning he is entangled and finally he reconciles with himself at the end. This may be the spiritual journey that everyone in the postmodern society must go through.

\section{References}

[1] Bauman, Z. (2000). Liquid Modernity. Cambridge: Polity Press.

[2] Bauman, Z. (2001). Consuming Life. Journal of Cosumer Culture, 1(1).

[3] Boparai, D. (2017, October 28). This week, Saudi Arabia granted citizenship to a robot and unveiled plans for a fully autonomous city. Retrieved from dezeen: https://www.dezeen.com/2017/10/28/this-week-architecture-design-news-roundup-saudi-arabia-sophia-robot-citizenship-neom-automated-city/

[4] Haraway, D. (1993). A Cyborg Manifesto. In S. During, The Cultural Studies Reader. London: Routledge. 